\title{
Function of organic matter (green manure) and the effect on soil properties
}

\begin{abstract}
Geeta Shrestha Vaidya, ${ }^{1}$ K. Shrestha ${ }^{2}$ and H. Wallander ${ }^{3}$
Trees and shrubs on the lower hillsides in Nepal form symbiosis with arbuscular mycorrhizal (AM) fungi and these fungi are important for the uptake of mineral nutrients from the soil and the mycelia formed by the fungi have an important function in stabilizing the soil (Wright and Upadhyaya 1998, Shrestha 1999 and Shrestha Vaidya et.al 2005a). The success of plantations of these eroded slopes is therefore highly dependent on the extent of mycorrhizal colonization of the plants.
\end{abstract}

In this study we have investigated the role organic matter on growth of an arbuscular mycorrhizal (AM) fungi in eroded slopes in Nepal such as Chalnakhel, Kathmandu District. Different types of organic matter (leaves of Thitonia diversifolia, Eupatorium adenophorum and Lantana camara) were collected and were shade dried and finally powedered. Nutrient analysis was done of these organic matter and soil of experimental site before plantation and after harvest. Lantana camara was taken for plantation on their nutrient content basis. 100 nursery plants Leuceania diversifolia plantation were done in Chalnakhel . Among these 50 plants with Lantana camara and 50 plants were for control. We investigated the influence of organic matter or $\mathrm{P}$ amendments on production of arbuscular mycorrhizal (AM) fungi in eroded slopes in Nepal. Organic matter addition enhanced the production of AM fungal biomass as well as number of AM spores. We suggest that the positive influence of such organic matter additions can make an important contribution to plant survival in plantations of eroded slopes in Nepal, and thus to restoration success.

Key Words : Organic matters (Lantana camara), arbuscular mycorrhizal fungi, Leuceania diversifolia and Chalnakhel.

O ganic matter is defined as a grouping of carbon compounds which have originated from living beings and deposited on or within the earth's structural components. Lal's (1993) initial definition of soil quality as the capacity of soil to produce economic goods and services and to regulate the environment "Soil quality".

Organic matter is a major source of plant nutrients and is the glue that holds soil particles together and stabilizes the pore structure. It makes soils less vulnerable to wind erosion and functions as a sponge for holding water and slowing down its loss from the root zone by drainage or evaporation. Moreover, nutrients added to soils as organic residues are released more gradually than those from mineral fertilizers and are therefore less prone to leaching, volatization or fixation. A fertile soil should contain from 2.8 percent organic matter, most soils contain less than 2 percent. Organic matter is a good source of phosphorus.

In addition to supplying nutrients, soil organic matter improves soil fertility by imparting favorable chemical and physical attributes to soil. Soil structure is influenced by the association of soil organic matter with minerals to form aggregates. Aggregate formation improves soil structure and water infiltration and improves root growth and provide habitat for a diversity of soil organisms. Soil organic matters (SOM) enhance nutrient cycling, provides habitat for a diversity of soil organisms, and creates a favorable environment for plant growth.

SOM is considered to be a key attribute of soil quality (Larson and Pierce, 1991; Gregorich et al., 1994) and also environmental quality (Smith et al., 2000). So, soil quality is considered a key element of sustainable agriculture (Warkentin, 1995).

It is involved in and related to many soil chemical, physical, and biological properties. It has a physical

\footnotetext{
Nepal Academy of Science and Technology, Khumaltar, Lalitpur, Nepal, E-mail: geetashrestha1@hotmail.com

Natural History Museum, Swambhu, Kathmandu, Nepal

Mycrobial Ecology Lab, Lund University, Lund, Sweden
} 
function in that it promotes good soil structure, thereby improving tilth, aeration and moisture movement and retention. Usually the greater the amount of organic matter in the soil the better is the physical properties of the soil. The organic materials also improve the microbial activities of the soil, biological $\mathrm{N}$ fixation, organic matter decomposition, mineralization, nitrification and antagonism to soil borne pathogens and fermentation are the common features of microbial activities in soil system (S.M.Alam, and M.A.Khan 2001).

The addition of organic matter such as green manure is a common practice used to improve soil nutrient content and soil structure. Addition of organic matter such as green manure is a common practice to improve soil nutrient content and soil structure. Organic residues from plants such as Tithonia diversifolia and Lantana camara have been found to be especially beneficial since they are reported to have a high content of $\mathrm{N}$ and $\mathrm{P}$, which is mineralized rapidly from the organic material. Nziguheba et al. (2000) found that P is released more rapidly from such organic residues than from triple superphosphate.

Most plants live in symbiosis with mycorrhizal fungi and these fungi improve water and nutrient uptake in exchange for carbohydrates supplied by the plant. Arbuscular mycorrhizal (AM) fungi form symbioses with most herbaceous and many woody plant species. Successful colonization by mycorrhizal fungi is especially important in degraded soils where nutrient availability is low.

\section{Materials and Methods}

This field experiment was conducted in Chalnakhel forest in central Nepal. This forest is situated in southern part of Kathmandu valley $12 \mathrm{~km}$. South of Kathmandu City near to Pharping. Study site was newly planted but there was too many spaces for plantation.

\section{Experiment design}

The experiment plot size was about $2 \mathrm{~m}$ spacing from each other and dug about $1 \mathrm{ft}$.

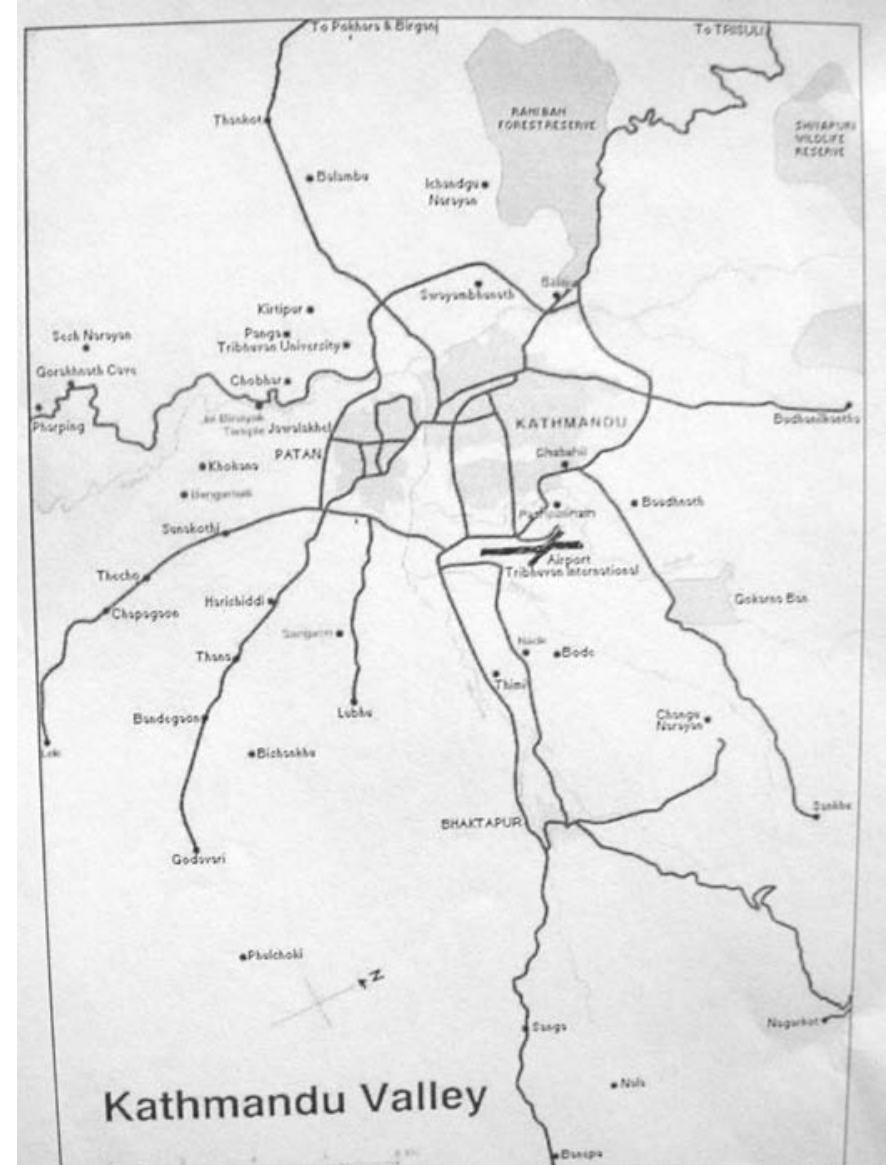

Nutrient analysis of the samples

Fresh leaves of Lantana camara, Tithonia diversifolia, Eupatorium adenophorum free from disease were collected from agro forestry and also from road side. These leaf materials were then shade dried and were finally powdered. The nutrient analysis were done of these green manures as well as soil of the plantation site also. These nutrient analysis was following Nitrogen, Potassium, Phosphorus, Organic matter and $\mathrm{pH}$ and was done in National Research Council (NARC), Soil Division, Khumaltar, Lalitpur Table 1. The site was selected in Chalnakhel. The AM spores extraction of the experimental soil was done before plantation and after harvest.

For plantation only one Lantana camara was taken . Total hundred replicates were taken. Among these fifty replicates for control without organic matter and fifty with organic matter such as Lenceania diversifolia. Total hundred Leuceania diversifolia one year old nursery plants were taken for plantation. These plants were six inches in height. Among these plants, the one year old 50 nursery plant Leuceania diversifolia was taken with organic matter (Lantana camara) and 50 plants were taken for control. These were planted in Chalnakhel about an one meter to two meter distance on June 2006. 200 gms powedered of Lantana camara was added. in each plant 50 Plants in the field experiment. These were harvested on May 2007. 


\section{Elemental anlysis of Plant and Soil Materials}

The fresh leaves of the plant species were air dried and ground to pass a $0.5 \mathrm{~mm}$ sieve. The Concentrations of $\mathrm{K}$ and $\mathrm{P}$ of dried plant leaves eroded soil were analyzed with ICP-AES. N was analyzed with an elemental analyzer (Elementar Analysensysteme $\mathrm{GmbH}$. Modell vario MAX CN.). Total nitrogen was determined using Kjeldhal's method. Walkey-Black's method was used for determining organic matter contain by wet digestion with $\mathrm{K}_{2} \mathrm{CR}_{2} \mathrm{O}_{7}$ and concentrated $\mathrm{H}_{2} \mathrm{So}_{4}$. Modified Olson's method was used for measuring available phosphorous ( with sodium bicarbonate) and P in leaves after digestion in nitric-perchloric acid (5:3) were determined by colorimetry, according to Murphy and Riley (1962s ). Available Potassium was determined using flame photometry after extraction by neutral and normal ammonium acetate solution. $\mathrm{pH}$ of the soil was determined with ratio of 1:1 (soil: water ratio). These data are reported in Table 1.

\section{Spore Analysis}

The AM fungal spores within $25 \mathrm{~g}$ of the soil of plantation site were extracted before plantation and after harvest and identified them. Spores were extracted using wet sieving and sucrose density gradient centrifugation (McKinney and Lindsey 1987). Spores were mounted in polyvinyl alcohol on slides and examined using a compound microscope. Species were identified to species using taxonomic characteristics described in INVAM (2005) and Schenck and Perez (1990).

Weigh $25 \mathrm{gm}$. of soil samples. Soil is mixed in a substantial volume of water and decanted through a series of sieves (750 Micron, 250 Micron, 100 Micron and 50 Micron) after allowing heavy soil particles to settle for a few minutes. This washing and decanting process is repeated until the water is clear. Roots and coarse debris are collected on a coarse. Then these finely kaolin clay remaining last sieve (50 Micron) transfer to centrifuge tube then was added water in equal weight of each four tube and then centrifuge it for 3 minutes at 2000 RPM. We should ensure that the centrifuge is properly balanced before switching it on. After this supernatant and floating debris was discarded.

The next step involves re-suspending the pellet in $50 \%$ sucrose by vigorously shaking tightly stopper tubes. The samples were then centrifuged for 1 minute at 2000 RPM to separate spores from denser soil components. Immediately after centrifugation, spores in the sucrose supernatant were poured onto the finest sieve (50 Micron) and carefully were washed with water to remove the sucrose.

After rinsing the spores, were washed them onto a pre-wetted filter paper in a Buchner funnel before vacuum filtration. In this we used what man filter paper for spore counting.

Semi- permanent microscope slide preparations of spores can be made using polyvinyl alcohol-lactoglycerol (PVLG) . Spores on microscope slides were squashed to reveal inner -wall layers and then were used dissecting microscope for identification. (Brundrett M et al1996 and N.C.Schenck and Yvonne Perez Third edition 1990). These spore extraction and identification was done in Nepal Academy of Science and Technology (NAST), Khumaltar, Lalitpur with the help of Dr.Prof. Nancy Johnson, Environmental and Biological Sciences, Northern Arizona University, USA Fig. 4 - 7. Spores were counted in each planted soil.

\section{Results and discussions}

After one year all these plantation were harvested . Among control five plants were died due to poor soil quality and low organic matter but with organic matter all the plants were survived. The height of plants were measured control as well as with organic matter.

Before field experiment number of spores per 25 gms. of soil have only 40 spores in average. In this Glomus species were more than that of Acaulospora species.

Table 1: Nutrient analysis of Organic matter and soil :

\begin{tabular}{|l|c|c|c|c|c|}
\hline \multicolumn{1}{|c|}{ Sample type } & $\mathbf{p H}$ & $\begin{array}{c}\text { Total } \\
\mathbf{N} \%\end{array}$ & $\begin{array}{c}\text { Available } \\
\mathbf{P ~ k g} / \mathbf{h a}\end{array}$ & $\begin{array}{c}\text { Available } \\
\text { K kg/ha }\end{array}$ & $\begin{array}{c}\text { Organic matter } \\
\mathbf{\%}\end{array}$ \\
\hline Tithonia diversifolia & - & 33.2 & 2,8 & 34.1 & 29.87 \\
\hline Lantana camara & - & 28.6 & 1.7 & 12.2 & 29.95 \\
\hline Eupatorium adenephorum & - & 36.7 & 2.6 & 22.6 & \\
\hline Soil before plantation & 7.3 & 0.12 & 6.0 & 94.0 & 14.94 \\
\hline Soil after plantation & 8.2 & 0.5 & 33.4 & 188.0 & 1.81 \\
\hline
\end{tabular}


After harvest average number of spores in control were 50 and with organic matter number of spores were present 250 per 25 gms. of soil Table 3 . In this five species were found such as Glomus macrcarpon, Glomus constrictum, Acaulospora spinosa, Acaulospora scobitulata and Acaulospora spinosa (Fig. 4-7). Average height of the plant with organic matter were $2.5 \mathrm{mt}$. and average height of plant in control were only 0.62 mt. Table 2.

\section{Discussion}

The beneficial role of organic matter may also be related to an improvement of physical properties like increased soil porosity and reduced mechanical resistance to hyphal growth through the soil (E.J.Joner et al. 1995). Giovanetti and Avio (1985) found that additions of different materials, which increased the pore volume in soil, had a beneficial effect on mycorrhizal growth response, colonization and spore numbers.

The production of recently formed extraradical AM mycelia is an important parameter since it may be directly related to the capacity of the plants to take up nutrients and to improvements of the soil structure and stability in degraded soils.

It is possible that nutrients such as $\mathrm{N}$ added with the organic matter have had a beneficial effect on the growth of AM fungi. In laboratory studies it has been found that N-containing organic matter, such as baker's yeast and bovine serum albumin, can have a stimulating effect on AM growth, while organic matter with higher $\mathrm{C}: \mathrm{N}$ ratios, such as cellulose and starch, can have inhibitory effects (Ravnskov et al. 1999). Geeta Shrestha Vaidya et al. 2007b have been found that Lantana camara having a higher $\mathrm{C}: \mathrm{N}$ ratio and lower $\mathrm{N}$ and $\mathrm{P}$ content than leaves from the other two agroforestry plants Tithonia diversifolia and Eupatorium adenephorum(green manure).
Furthermore it has been shown that the decomposition rates and $\mathrm{N}$ and $\mathrm{P}$ mineralization from litter of these and similar plants is highly correlated to total P content (Kwabiah et al. 2001). Species of AM fungi (Douds \& Schenck, 1990) and other soil microorganisms McKinley et al. (2005) differ in their responses to soil $\mathrm{C}, \mathrm{N}$ and $\mathrm{P}$ availability.

The addition of compost or green manure is an important way to improve the soil in degraded areas since nitrogen and other nutrients, as well as organic matter which improves soil structure, is added with the organic material (Caravaca et al. 2002; Muthukumar \& Udaiyan, 2000, Nziguheba et al. 2000 and Geeta Shrestha Vaidya et alm2007a).

Improved nutrient and water uptake by the planted trees can be expected in response to better AM growth and the positive effect on the growth of AM fungi is in good agreement with results obtained by other authors (Douds et al. 1997; Baby \& Manibhushanrao 1996; Muthukumar \& Udaiyan, 2000; Gryndler et al. 2002; Harinikumar \& Bagyaraj 1989; Jamil Mohammed et al. 2003; Jeffries \& Barea (2001). In addition, St John et al. (1983), Frey \& Ellis (1997) and Friberg (2001) found that AM fungal hyphae grew best in soils with a high amount of organic matter.

The present study provides the first information on a stimulating effect of organic material addition on extra-radical growth of AM fungi in eroded slopes in Nepal. These results show that organic matter addition can improve plant growth survival in such areas, and it also help for soil quality due to increasing rate endomycorrhiza (AM spores).

\section{Recommendation}

The interest in organic agriculture as well as in forestry in developing countries is growing because it requires

Table 2: Average Height of Plants

\begin{tabular}{|c|l|c|}
\hline No. & \multicolumn{1}{|c|}{ Treatment } & Average Plant height \\
\hline 1. & Plantation of nursery plant with Lantana camara & $2.5 \mathrm{mt}$. \\
\hline 2. & Plantation only nursery plant without Lantana camara & $0.62 \mathrm{mt}$. \\
\hline
\end{tabular}

In this the plant with organic matter had more height than that of control.

Table 3:

\begin{tabular}{|c|l|c|}
\hline No. & \multicolumn{1}{|c|}{ Treatment } & $\begin{array}{c}\text { Spores present in 25 gms. of } \\
\text { soil }\end{array}$ \\
\hline 1. & Plantation of nursery plant with Lantana camara & 250 \\
\hline 2. & Plantation only nursery plant without Lantana camara & $\mathbf{5 0}$ \\
\hline
\end{tabular}

In this the soil with organic matters (Lantana camara) had many spores and control had only few. 
less financial input and places more reliance on the natural and human resources available. Organic fertilizers offers comparative advantage in soil quality. In this we know that local wastages green manure materials could use for organic fertilizers. So, I want to highly recommended that this type of work should continue in future also. In the context of our country, farmers and growers should be educated to reduce the conventional chemical fertilizers all farmers should know the impact of those chemical fertilizers in the soil. It deteorated the soil quality. Hopefully, the use of green manure in trial will be beneficial to the farmers to grow organic forest rendering no harm to the environment and the soil.

\section{Conclusion}

Organic amendments significantly increased AM fungal biomass in eroded slopes of Nepal. AM fungi is an important parameter because it can be directly related to the capacity of host plants to acquire nutrients and improve soil structure and stability in degraded soils. In this case, the higher forest product with applications of the higher quality Lantana are due to a combination of more $\mathrm{P}$ and $\mathrm{N}$ added and faster release patterns of $\mathrm{P}$ and $\mathrm{N}$ from Lantana as compared to control.

It has been shown that appropriate management of mycorrhizae in forest allows a substantial reduction in the use of chemicals, thus lessening the level of pollution and it keeps the soil in good quality and it has bio-control properties also. The use of green manure in forest and in turn contribute to the development of a healthy and sustainable soil and as well as environment So, finally it can conclude that Organic matter (local wastages green manure) content is usually higher in organically fertility and stability of organic soils as well as moisture retention capacity from which it reduces the risk of erosion and desertification.

\section{Acknowledgement}

We would like to thank Dr.B.R.Khadge, Chief of Plant Pathology, Division, National Agriculture Research Centre (NARC), Khumaltar, Lalitpur, Nepal for his valuable suggestion and also thsnkful to staff of Chalnakhel nursery to their help during the experiment.

\section{References}

Alam S. M., and Khan, M. A. 2001. Organic and effective micro-organisms (EM) technology, http://www.pakistaneconomist.com/issue2001/ issue26/i\&e6.htm

Anderson, R. C., A. E. Liberta, L. A. Dickman and A. J. Katz. 1983. Spatial variation in vesicular arbuscular mycorrhiza spore density. Bulletin of the Torrey Botanical Club 110:519 525.

Baby, U. I. and K. Manibhushanrao. 1996. Influence of organic amendments on arbuscular mycorrhizal fungi in relation to rice sheath blight disease. Mycorrbiza. 6:201-206.

Boddington, C. L. and J. C. Dodd. 2000. The effect of agricultural practices on the development of indigenous arbuscular mycorrhizal fungi. I. Field studies in an Indonesian ultisol. Plant and soil. 218:137 144 .

Brundrett, M., Bougher, B., Dell, Grove, T. and Maljczuk, N. 1996. Working with Mycorrhizas in forestry and agriculture. ACIAR Monograph 32: 155-137

Caravaca, F. J., Barea, M. and Roldán, A. 2002. Synergistic influence of an arbuscular mycorrhizal fungus and organic amendment on Pistacia lentiscus L. seedlings afforested in a degraded semi-arid soil. Soil Biology and Biochemistry 34:1139-1145.

Degens, B. P., Sparling, G. P., Abbot, L. K. 1996 Increasing the length of hyphae in a sandy soil increases the amount of water - stable aggregates. Applied Soil Ecology 3. 149-159.

Douds, D. D., Galvez, L., Franke-Snyder, M., Reider, G. and Drinkwater, L. E. 1997. Effect of compost addition and crop rotation point upon VAM fungi. Agriculture, Ecosystems ands Environment. 65:257266

Douds, D. D., Schenck, N. C. 1990. Relationship of colonization and sporulation by VA mycorrhizal fungi to plant nutrient and carbohydrate contents. New Phytologist 116:621-627.

Frey, J. E. and Ellis, J. R. 1997. Relationship of soil properties and soil amendments to response of Glomus intraradices and soybeans. Canadian Journal of Botany 75:483-491.

Friberg, S. 2001. Distribution and diversity of arbuscular mycorrhizal fungi in traditional agriculture on the Niger inland delta, Mali, West Africa. CBM:s Skriftserie. 3:53-80.

Gaur, A. and Adholeya, A. 2002. ArbuscularMycorrhizal inoculation of five tropical fodder crops and inoculum production in marginal soil amended with organic matter. Biology and Fertility of Soils 35:214-218. 
Giovanetti M and L. Avio. 1985. VAM infection and reproduction as influenced by different organic and inorganic substances. In Proceeding of the $6^{\text {th }}$ NorthAmerican Conference on Mycorrhizae (Molina, R. (ed) Forest Research Laboratory. Bend, Oregon.

Gryndler, M., Vosátka, M.,Hršelová, H., Chvátalová, I. and Jansa, J. 2002. Interaction between arbuscular mycorrhizal fungi and cellulose in growth substrate. Applied Soil Ecology. 19:279-288.

Harinikumar, K. M. and Bagyaraj, D. J. 1989. Effect of cropping sequence, fertilizers and farmyard manure on vesicular-arbuscular mycorrhizal fungi in different crops over three consecutive seasons. Biology and Fertility of Soils. 7:173-175.

Harley, J. L. and Smith, S. E. 1983. Mycorrhizal symbiosis. Academic press. New York pp. 483.

Holm, L. G., Plucknett, D. L., Pancho, J. V. and Herberger, J. P. 1977. The word's worst weeds. Distribution and biology. University Press of Hawaii: Honolulu.

INVAM, 2005. International Culture Collection of Arbuscular and VA Mycorrhizal Fungi http:// invam.caf.wvu.edu/.

Jagannath, J., Bhattarai, T. N., Sthapit, K. M. and Omura, H. 1998. Soil erosion and sediment disaster in Nepal-A review. Journal of the Faculty of Agriculture 42:491-502.

Jastrow, J. D., Miller, R. M., Lussenhop, J. 1998. Contributions of interacting biological mechanisms to soil aggregate stabilization in restored prairie Soil Biology and Biochemistry 30, 905 916.

Johnson, N. C., and McGraw, A. C. 1988. Vesiculararbuscular mycorrhizae in taconite tailings II. Effects of reclamation practices. Agriculture Ecosystems and Environment 21:143-152.

Koske, R. E. 1987. Distribution of VA mycorrhizal fungi along a latitudinal temperature gradient. Mycologia. 79:55-68.

Kwabiah, A. B., Stoskopf, N. C., Voroney, R. P. and Palm, C. A. 2001. Nitrogen and Phosphorus Release from Decomposing Leaves under SubHumid Tropical Conditions. Biotropica 33:229-240.

McKenney, M. C., and Lindsey, D. L. 1987. Improved method for quantifying endomycorrhizal fungi spores from soil. Mycologia 79:779-782.
McKinley, V. L., Peacock, A. D., and White, D. C. 2005. Microbial community PLFA and PHB responses to ecosystem restoration in tallgrass prairie soils. Soil Biology and Biochemistry 37:19461958.

Muthukumar, T., and Udaiyan, K. 2000. Influence of organic manures on arbuscular mycorrhizal fungi associated with Vigna unguiculata (L.) Walp. in relation to tissue nutrients and soluble carbohydrate in roots under field conditions. Biology and Fertility of Soils 31:114-120.

Nziguheba, G., R. Merckx, C. A. Palm and M. R. Rao. 2000. Organic residues affect phosphorus availability and maize yields in a Nitisol of Western Kenya. Biology and Fertility of Soils 32:328-339

Olsson PA. 1999. Signature fatty acids provide tools for determining of the distribution and interactions of mycorrhizal fungi in soil. FEMS Microbiology Ecology 29: 303-310.

Porter, W. M., A. D. Robsen, and L. K. Abott. 1987. Field survey of the distribution of vesicular arbuscular mycorrhizal fungi in relation to soil $\mathrm{pH}$. Journal of Applied Ecology 24:659-662.

Ravnskov, S., Larsen, J., Olsson, P. A. and Jakobsen, I. 1999. Effects of various organic compounds on growth and phosphorus uptake of an arbuscular mycorrhizal fungus. New Phytologist. 141:517-524.

Ryan, M. H., Chilvers, G. A. and Dumaresq, D. C. 1994. Colonisation of wheat by VA- mycorrhizal fungi was found to be higher on a farm managed in an organic manner than on a conventional neighbour. Plant and Soil 160:33-40.

Schaffiner R. 1999 Regeneration of vegetation on stabilising and eroding slopes in eastern Nepal: An evaluation 14 years after the first survey. Bulletin of the Geobotanical Institute ETH 65, 43-58.

Schenck, N. C., and Y. Perez. 1990. Manual for the identification of VA mycorrhizal fungi. Synergistic Publications, Gainesville, Florida, USA.

Shrestha, G. 1999. Ectomycorrhizal effect of Mushrooms of Pine Forest of Nepal. Proceeding of Third National Conference on Science and Technology, 8-11 March, pp. 1271-1276, organized by RONAST, Kathmandu, Nepal. 
Shrestha, G. 1999. The role of Ectomycorrhizae in Forestry Development in Nepal. Proc. "8th. International workshop of BIO-REFOR, 28-29 November pp. 178-182.

Shrestha Vaidya Geeta and Keshab Shrestha 2005. Performance of Pinus Roxburghii Inoculated with pure Culture of Four Indigenous Ectomycorrhizal Fungi. Nepal Journal of Science and Technology 6 : 41-46.

Shrestha Vaidya G., Shrestha, K., Khadge, B. R., Johnson, N. C. and Wallander, H. (2007). Organic matter stimulates arbuscular mycorrhizal fungi in Baubinia purpurea and Leucaenia diversifolia plantations on eroded slopes in Nepal accepted by restoration Ecology, UK, in press.
Smith, S. E., and Ready, D. J., 1997. Mycorrhizal symbiosis. Academic Press San Diego.

St. John, T. V., Coleman, D. C. and Reid, C. P. P. 1983. Association of vesicular arbuscular mycorrhizal hyphae with soil organic particles. Ecology 64:957959.

Tisdall, J. M., Oades, J. M. 1979. Stabilization of soil aggregates by the root systems of ryegrass. Austral J. Soil Res. 17, 429-441.

Van Aarle, I. M., Olsson, P. A. and Soderstrom, B. 2002. Arbuscular mycorrhizal fungi respond to the substrate $\mathrm{pH}$ of their extraradical mycelium by altered growth and root colonization. New Phytopatholist. 155: 173-182. 


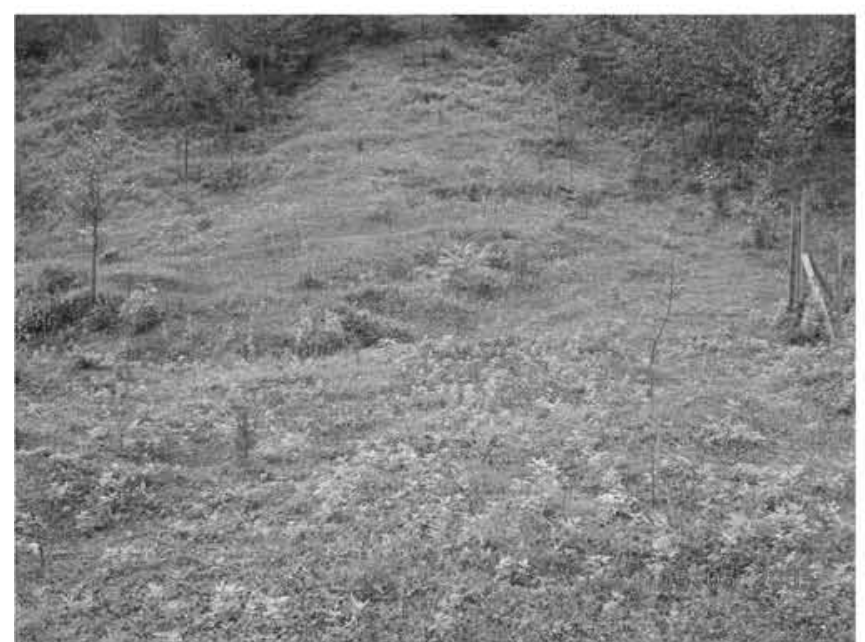

Fig. 1 : Before plantation (Chalnakhel forest)

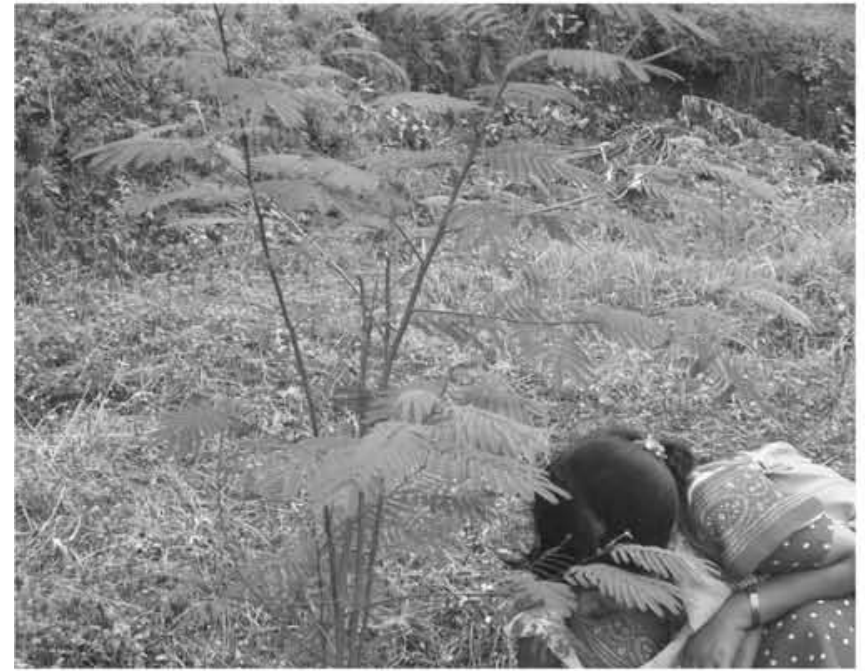

Fig. 3 : Plantation after one year (with Lantana camara)

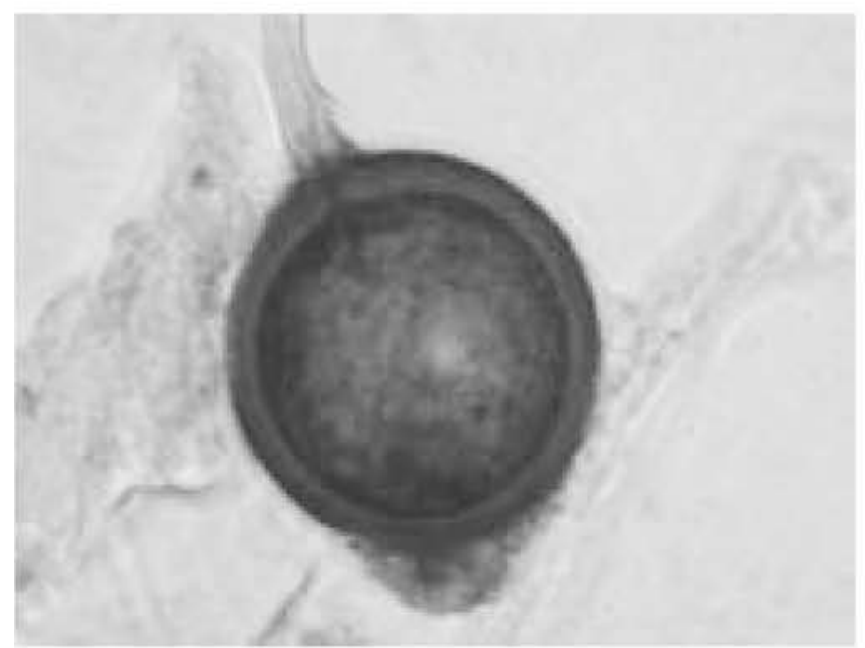

Fig. 5 : Glomus constrictum

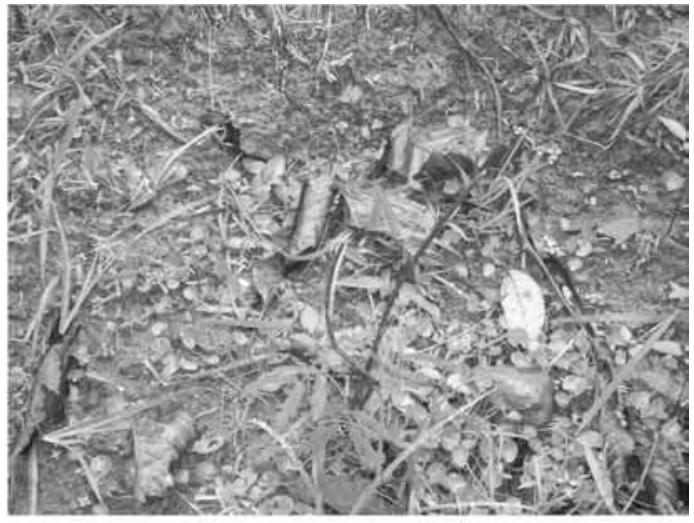

Fig. 2 : Plantation after one year (Control)

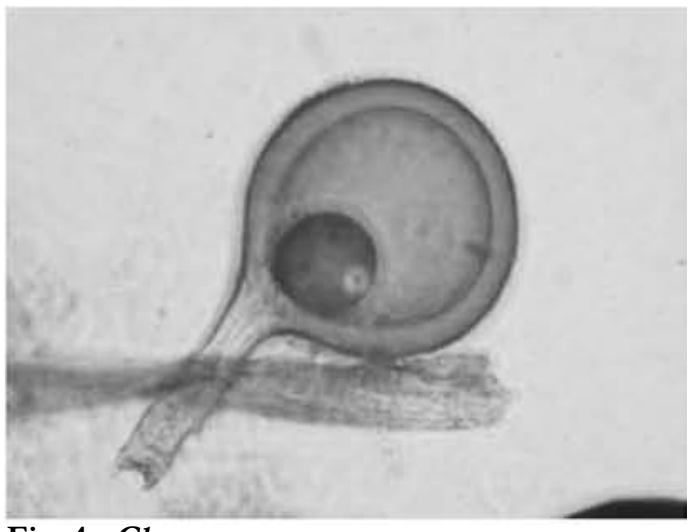

Fig. 4 : Glomus macrcarpon

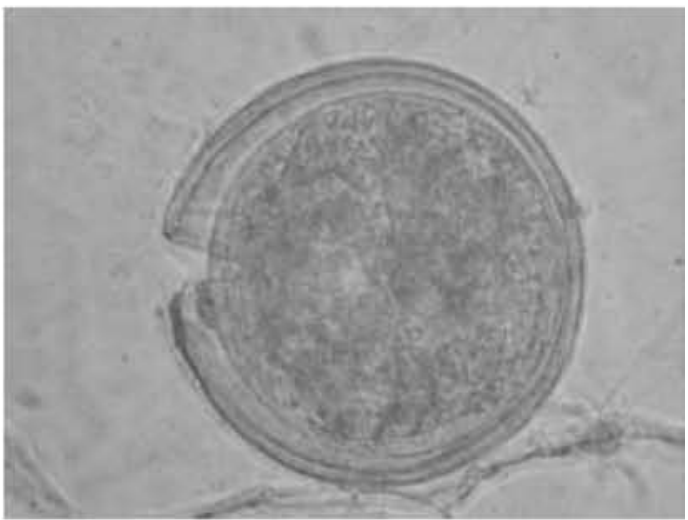

Fig. 6 : Acaulospora spinosa

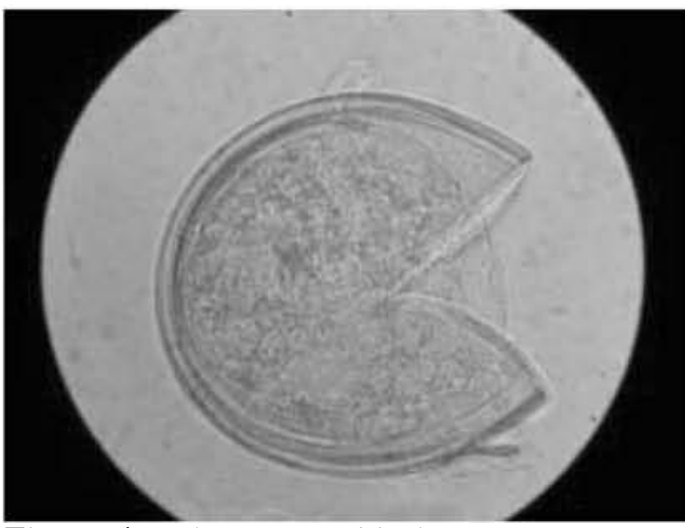

Fig. 7 : Acaulospora scobitulata 